\title{
Genetic Variability and Association Analysis in Elite Rice (Oryza sativa L.) Germplasm
}

\author{
Sudhir K. Pathak, Neha Srivastava*, G. Roopa Lavanya and G. Suresh Babu \\ Department of Genetics and Plant Breeding, Naini Agricultural Institute, \\ Sam Higginbottom University of Agriculture, Technology and Sciences, \\ Allahabad - 211007 (Uttar Pradesh), India \\ *Corresponding author
}

Ke y w o r d s
Correlation, Genetic
variability,
Heritability and
Rice

\section{A B S T R A C T}

A study was conducted during kharif 2013 at SHUATS, Allahabad in randomized block design to evaluate genetic variation and heritability of yield and related traits in 98 rice genotypes Genetic variability and character association between yield and its contributing traits were studied in 98 elite rice germplasm. Analysis of variance revealed the existence of significant differences among genotypes for all characters studied. Higher magnitude of GCV \& PCV was recorded for biological yield/plant followed by grain yield per plant, flag leaf length, number of tiller/plant and flag leaf width. While moderate was recorded for spikelet per panicle, harvest index, panicle per plant and test weight. High heritability coupled with high genetic advance as per cent of mean was observed for biological yield and spikelet's per panicle indicating the role of additive gene in expressing these traits. Grain yield was significant highly positively correlated with biological yield, flag leaf length, spikelet per panicle, panicle length.

\section{Introduction}

Rice as one of the principle food crops is no longer a luxury food but has become the cereal that constitutes a major source of calories $(43 \%)$ for the urban and rural poor (Ogunbayo et al., 2005; Seck et al., 2013). In India, rice is grown in an area of 44.2 million ha $(23 \%$ of gross cropped area) with an annual production of 104.32 million tons. The productivity level of rice in India is very low (3.21 tons per hectare) (Directorate of economics and statistics, 2016-17). Thus to increase the yield, which is highly influenced by the environment, hence direct selection for yield alone limit the selection efficiency and 
ultimately results in limited success in yield improvement. Therefore, by exploiting the good adaptation and stability of yield and its components in rice genotypes, it would be possible to develop/identify high yielding and well adapted varieties (Ogunbayo, 2011). Thus, effective yield component breeding to increase grain yield could be achieved, if the components traits are highly heritable and positively correlated with grain yield (Ullah et al., 2011). Genetic variability studies are important in selection of parents for hybridization because crop improvement depends upon magnitude of genetic variability in base population (Adebisi et al., 2001). Once genetic variability has been ascertained, crop improvement is possible through the use of appropriate selection method and increasing total yield would be made easier by selecting for yield components because they are more often easily inherited than total yield itself. Knowledge of interrelationship of the phenotypic traits among each other and their influence on yield of various traits towards yield is important in a breeding programme and in selecting suitable lines for subsequent release as new varieties. An attempt was made in the present investigation to assess the variability, heritability and genetic advance of some quantitative characters and understand the relationship between these characters and their contribution to yield in a set of genotypes.

\section{Materials and Methods}

Field experiment was conducted at field experimentation center, Department of Genetics and Plant Breeding, Allahabad School of Agriculture, Sam Higginbottom University of Agriculture, Technology and Sciences, Allahabad, U.P. during kharif 2013. The experimental material comprised of ninety eight entries including checks were sown in randomized complete block design (RBD) with three replications with a spacing of $15 \mathrm{~cm}$ between the rows and $15 \mathrm{~cm}$ between the plants. Observations were recorded on five randomly selected plants in each replication. The characters studied were days to $50 \%$ flowering, plant height $(\mathrm{cm})$, flag leaf length, flag leaf width, productive tillers per plant, number of panicle per plant, panicle length $(\mathrm{cm})$, days to maturity, biological yield per plant, number of grains per panicle, test weight $(\mathrm{g})$, harvest index and grain yield per plant $(\mathrm{g})$. The mean values were used for analysis of variance. The coefficient of variation was calculated as per Burton (1952). Heritability in broad sense and genetic advance were calculated as per Johnson et al., (1955). The correlation coefficients was carried out following the methods of AlJibouri et al., (1958).

\section{Results and Discussion}

The success of any breeding programme depends upon the extent of genetic variability in base population and relationship of various characters towards yield. In the present study the analysis of variation shown highly significant differences among the genotypes for all the characters studied viz., days to $50 \%$ flowering, plant height $(\mathrm{cm})$, flag leaf length, flag leaf width, productive tillers per plant, number of panicle per plant, panicle length (cm), days to maturity, biological yield per plant, number of grains per panicle, test weight $(\mathrm{g})$, harvest index and grain yield per plant (g) indicating the existence of considerable genetic variation in the experimental material.

Perusal the components of variance revealed that the phenotypic coefficient of variation (PCV) were higher than Genotypic coefficient of variation (GCV) for all the characters studied indicating the role of environmental variance in the total variance (Table 1). Higher magnitude of GCV \& PCV was recorded for biological yield/plant followed 
by grain yield per plant, flag leaf length, number of tiller/plant and flag leaf width. While moderate was recorded for spikelet per panicle, harvest index, panicle per plant and test weight (Roy et al., 2001). Heritability in broad sense was higher in most of the characters viz., biological yield per plant $(98 \%)$ followed by spikelet per panicle $(965 \%)$ and grain yield per plant $(95 \%)$. Johnson et al., (1955) had pointed out that in a selection programme, heritability values as well as genetic advance were more useful than heritability alone. High heritability coupled with high genetic advance as percent of mean was observed in biological yield and spikelet's per panicle indicating the role of additive gene in expressing these traits and revealed better scope for improvement of these traits through direct selection.

Table.1 Estimates of variability, heritability and genetic advance in Rice

\begin{tabular}{|c|c|c|c|c|c|c|c|c|c|c|c|c|c|}
\hline Characters & $\begin{array}{l}\text { Days to } \\
\mathbf{5 0 \%} \\
\text { Flowering }\end{array}$ & $\begin{array}{l}\text { Plant } \\
\text { Height } \\
\text { cm }\end{array}$ & $\begin{array}{l}\text { Tillers/ } \\
\text { Plant }\end{array}$ & $\begin{array}{l}\text { Panicles/ } \\
\text { Plant }\end{array}$ & $\begin{array}{l}\text { Flag } \\
\text { Leaf } \\
\text { Length }\end{array}$ & $\begin{array}{l}\text { Flag } \\
\text { Leaf } \\
\text { Width }\end{array}$ & $\begin{array}{l}\text { Panicle } \\
\text { Length } \\
\text { cm }\end{array}$ & $\begin{array}{l}\text { Days to } \\
\text { Maturity }\end{array}$ & $\begin{array}{l}\text { Biological } \\
\text { Yield/ } \\
\text { Plant }\end{array}$ & $\begin{array}{l}\text { Harvest } \\
\text { Index }\end{array}$ & $\begin{array}{l}\text { Spikelets/ } \\
\text { Panicle }\end{array}$ & $\begin{array}{l}\text { Test } \\
\text { Weight }\end{array}$ & $\begin{array}{l}\text { Grain } \\
\text { Yield/ } \\
\text { Plant }\end{array}$ \\
\hline GCV & 7.43 & 11.23 & 13.92 & 10.91 & 17.50 & 11.04 & 9.51 & 5.37 & 27.59 & 14.54 & 15.72 & 13.30 & 24.18 \\
\hline PCV & 8.41 & 12.85 & 17.64 & 15.46 & 18.77 & 17.13 & 11.00 & 6.02 & 27.82 & 15.95 & 16.13 & 15.14 & 24.84 \\
\hline $\mathbf{h}^{2}($ Broad Sense $) \%$ & 78.00 & 76.00 & 62.00 & 50.00 & 87.00 & 42.00 & 75.00 & 79.00 & 98.00 & 83.00 & 95.00 & 77.00 & 95.00 \\
\hline $\begin{array}{l}\text { Genetic } \\
\text { Advancement 5\% }\end{array}$ & 12.79 & 21.70 & 2.81 & 1.69 & 10.77 & 0.18 & 4.15 & 12.78 & 32.36 & 10.41 & 53.91 & 4.88 & 10.41 \\
\hline $\begin{array}{l}\text { Gen.Adv as \% of } \\
\text { Mean 5\% }\end{array}$ & 13.51 & 20.20 & 22.64 & 15.86 & 33.62 & 14.66 & 16.94 & 9.85 & 56.37 & 27.31 & 31.56 & 24.06 & 48.48 \\
\hline General Mean & 94.62 & 107.42 & 12.43 & 10.64 & 32.03 & 1.26 & 24.52 & 129.73 & 57.41 & 38.13 & 170.82 & 20.29 & 21.48 \\
\hline
\end{tabular}

Table.2 Estimation of Genotypic Correlation Matrix (upper diagonal) and phenotypic Correlation Matrix (lower diagonal) between yield and its related traits among 98 rice genotypes during kharif 2013

\begin{tabular}{|c|c|c|c|c|c|c|c|c|c|c|c|c|c|}
\hline $\begin{array}{l}\text { Chara } \\
\text { cters }\end{array}$ & DFF & PH & TPP & FLL & FLW & PPP & PL & SP/P & DM & TW & BY/P & HI & GY/P \\
\hline DFF & 1.00 & 0.07 & $-0.31 * *$ & -0.08 & -0.09 & $-0.16^{* *}$ & $-0.11 *$ & 0.01 & $1.00 * *$ & $-0.33 * *$ & -0.02 & -0.07 & -0.09 \\
\hline PH & 0.05 & 1.00 & $0.10^{*}$ & $0.27 * *$ & $0.30 * *$ & $0.24 * *$ & $0.40 * *$ & $0.28 * *$ & 0.08 & $0.18 * *$ & $0.23^{* *}$ & $0.10^{*}$ & $0.30 * *$ \\
\hline TPP & $-0.24 * *$ & $0.14^{*}$ & 1.00 & $0.13^{*}$ & 0.01 & $0.90 * *$ & 0.05 & $-0.18 * *$ & $-0.28 * *$ & $0.19 * *$ & $0.29 * *$ & $-0.27 * *$ & $0.14 *$ \\
\hline FLL & -0.04 & $0.28 * *$ & $0.12 *$ & 1.00 & $0.36^{* * *}$ & $0.11^{*}$ & $0.48 * *$ & $0.46^{* *}$ & -0.05 & 0.01 & $0.42 * *$ & $0.11^{*}$ & $\mathbf{0 . 5 3} * *$ \\
\hline FLW & -0.08 & $0.30 * *$ & $0.11^{*}$ & $0.33 * *$ & 1.00 & 0.09 & -0.02 & $0.33 * *$ & -0.05 & 0.04 & $0.28 * *$ & -0.08 & $0.21 * *$ \\
\hline PPP & -0.06 & $0.17 * *$ & $0.54^{* *}$ & $0.11 *$ & 0.08 & 1.00 & $0.21 * *$ & $-0.16^{* *}$ & $-0.14^{*}$ & $0.33 * *$ & $0.34 * *$ & $-0.22 * *$ & $0.21 * *$ \\
\hline PL & -0.08 & $0.36 * *$ & 0.07 & $0.47 * *$ & $0.16^{* *}$ & $0.14 *$ & 1.00 & $0.25^{* *}$ & $-0.11 *$ & $0.31 * *$ & $0.32 * *$ & 0.02 & $0.37 * *$ \\
\hline SP/P & 0.01 & $0.24 * *$ & $-0.13^{*}$ & $0.42 * *$ & $0.20 * *$ & 0.03 & $0.22 * *$ & 1.00 & 0.04 & -0.01 & $0.21 * *$ & $0.23 * *$ & $0.41 * *$ \\
\hline DM & $0.99 * *$ & 0.05 & $-0.23 * *$ & -0.03 & -0.07 & -0.07 & -0.08 & 0.03 & 1.00 & $-0.23^{* *}$ & 0.003 & -0.08 & -0.07 \\
\hline TW & $-0.24 * *$ & $0.22^{* *}$ & $0.16^{* *}$ & $0.10^{*}$ & $0.18^{* *}$ & $0.21 * *$ & $0.31 * *$ & -0.01 & $-0.25 * *$ & 1.00 & $0.20 * *$ & -0.03 & $0.20 * *$ \\
\hline BY/P & -0.002 & $0.22^{* *}$ & $0.23 * *$ & $0.39 * *$ & $0.20 * *$ & $0.24 * *$ & $0.28 * *$ & $0.20 * *$ & 0.001 & $0.19 * *$ & 1.00 & $-0.45^{* *}$ & $0.78 * *$ \\
\hline HI & -0.06 & 0.09 & $-0.19 * *$ & $0.10^{*}$ & $0.33^{* *}$ & $-0.12^{*}$ & 0.06 & $0.21^{* *}$ & -0.06 & -0.002 & $-0.42 * *$ & 1.00 & $0.16 * *$ \\
\hline GY/P & -0.07 & $0.27 * *$ & $0.14 *$ & $0.49 * *$ & $0.17 * *$ & $0.15 * *$ & $0.35 * *$ & $0.39 * *$ & -0.05 & $0.18 * *$ & $0.76 * *$ & $0.22 * *$ & 1.00 \\
\hline
\end{tabular}

$\mathrm{DFF}=$ Days to $50 \%$ flowering, $\mathrm{DM}=$ Days to maturity, FLW= flag leaf width, $\mathrm{PL}=$ Panicle length, NTP= Number of productive tillers per plant, $\mathrm{PH}=\mathrm{Plant}$ height, $\mathrm{PPP}=\mathrm{Panicle}$ per plant, $\mathrm{TW}=$ Test weight, $\mathrm{NSP}=$ Number of spikelets per panicle, $\mathrm{BYP}=\mathrm{Biological}$ yield/plant, $\mathrm{HI}=$ Harvest index, GYP= Grain yield per plant 
Grain yield is a complex character governed by several contributing traits. Hence, it is important to understand the association of different characters with Grain yield for enhancing the usefulness of selection criterion to be followed while developing varieties. In the present investigation the genotypic and phenotypic correlations are on par with each other suggesting the less influence of environment (Table 2). Invariably Grain yield was significant positively correlated with biological yield (0.78), flag leaf length (0.53) number of spikelet per panicle (0.41), plant height $(0.30)$, flag leaf width $(0.21)$, panicle per plant $(0.21)$, test weight $(0.20)$, harvest index (0.16), tiller per plant (0.14) (Raju et $a l ., 2004)$ and panicle length (Rajeshwari and Nadarajan, 2004) were noticed in their respective experiments.

In conclusion, the present study indicates that there is adequate genetic variability present in the material studied. Biological yield per plant and seed yield per plant show high GCV and PCV while biological yield per plant and spikelet's per panicle exhibited high heritability, biological yield per plant and number of spikelet's per panicle also coupled with high genetic advance and as percent of mean. Hence these characters also showed positive correlation with seed yield per plant. Spikelet per panicle is the most important traits which should be given due attention in making selection effective for high yielding genotypes. Therefore, from present study it can be forwarded that for increasing rice grain, a genotype should posses more number of grains per panicle. Since one year data is not sufficient to conclude concurrent result. So, future experimentation is required to confirm the result.

\section{References}

Adebisi M. A., Ariyo O. J. and Kehinde O. B. (2001). Variation and Correlation studies in quantitative characteristics in soybean. Proceedings of the 35th Annual conference of the Agricultural Society of Nigeria held at the University of Agriculture, Abeokuta September; 16 -20 , Pp. $121-125$.

Al-Jibouri, H., Miller, P. A. and Robinson, H. F. (1958). Genotypic and environmental variances and covariance's in an upland cotton crosses of interspecific origin. Agron. J. 50: 633-637

Burton, G.W. (1952). Quantitative inheritance in grasses Proc. 6th Grassland Congr., 1: 356-363

Johnson, H.W., Robinson, H.F. and Comstock, R.E. (1955). Estimates of genetic and environmental variability in soyabeans. Agronomy Journal. 47: 314318

Directorate of Economics and Statistics, (2016-17).

Ogunbayo SA (2011). Genetic variation, correlation studies and multilocational performance of lowland NERICA Rice (Oryza species L). PhD Thesis, Federal University of Agriculture, Abeokuta, Nigeria.

Ogunbayo SA, Ojo DK, Guei RG, Oyelakin O, Sanni KA (2005). Phylogenetic diversity and relationship among forty rice accessions using Morphological and RAPDs techniques. Afr. J. Biotechnol. 4:1234-1244.

Rajeshwari, S. and Nadarajan, N., (2004). Correlation between yield and yield components in rice (Oryza sativa L.). Agric. Sci. Digest., 24: 280-282. Raju, C. H. S., Rao, M. V. B. and Suarshanam, A., (2004). Genetic analysis and character association in F2 generation of rice. Madras Agric. J., 91: 66-69.

Roy B., M. Hossain and F. Hossain. (2001). Genetic variability in yield components of rice (Oryza sativa). Environmental and Ecology, 19(1):186 - 189. 
Seck PA, Toure AA, Coulibaly JY, Diagne A, Wopereis MCS (2013). Africa's Rice Economy before and after 2008 rice crisis pp. 24-34. In: Wopereis MCS, Johnson DE, Ahmadi N, Tollens E, Jalloh A (Eds), Realizing Africa's Rice Promise. CABI International (UK) and
AfricaRice (Benin) $480 \mathrm{pp}$. Ullah MZ, Bashar MK, Bhuiyan MSR, Khalequzzaman M, Hasan MJ (2011). Interrelationship and cause-effect analysis among morphophysiological traits in biroin rice of Bangladeshi. Int. J. Plant Breed. Genet. 5:246-254.

\section{How to cite this article:}

Sudhir K. Pathak, Neha Srivastava, G. Roopa Lavanya and Suresh Babu, G. 2020. Genetic Variability and Association Analysis in Elite Rice (Oryza sativa L.) Germplasm. Int.J.Curr.Microbiol.App.Sci. 9(05): 2149-2153. doi: https://doi.org/10.20546/ijcmas.2020.905.245 